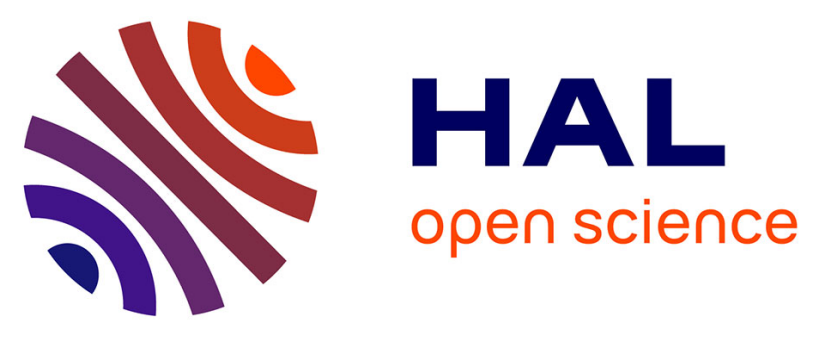

\title{
Tensions in Information System Artefacts: Explaining Land Information Systems' Sub-optimal Impact in Indonesia
}

Fathul Wahid, Øystein Sæbø, Bjørn Furuholt

\section{To cite this version:}

Fathul Wahid, Øystein Sæbø, Bjørn Furuholt. Tensions in Information System Artefacts: Explaining Land Information Systems' Sub-optimal Impact in Indonesia. 14th International Conference on Social Implications of Computers in Developing Countries (ICT4D), May 2017, Yogyakarta, Indonesia. pp.765-777, 10.1007/978-3-319-59111-7_62 . hal-01650046

\section{HAL Id: hal-01650046 \\ https://hal.inria.fr/hal-01650046}

Submitted on 28 Nov 2017

HAL is a multi-disciplinary open access archive for the deposit and dissemination of scientific research documents, whether they are published or not. The documents may come from teaching and research institutions in France or abroad, or from public or private research centers.
L'archive ouverte pluridisciplinaire HAL, est destinée au dépôt et à la diffusion de documents scientifiques de niveau recherche, publiés ou non, émanant des établissements d'enseignement et de recherche français ou étrangers, des laboratoires publics ou privés. 


\title{
Tensions in Information System Artefacts: Explaining Land Information Systems' Sub-Optimal Impact in Indonesia
}

\author{
Fathul Wahid ${ }^{1,2}$,Øystein Sæbø ${ }^{2}$ and Bjørn Furuholt ${ }^{3}$ \\ ${ }^{1}$ Department of Informatics, Universitas Islam Indonesia, Yogyakara, Indonesia \\ ${ }^{2,3}$ Department of Information Systems, University of Agder, Kristiansand, Norway \\ ${ }^{1}$ fathul.wahid@uii.ac.id, 2oystein.sabo@uia.no, \\ ${ }^{3}$ bjorn. furuholteuia.no
}

\begin{abstract}
Despite the advancement of more integrated land information systems (LIS), conflicts and disputes over land in Indonesia remain. Our study seeks to explain this situation. Using an interpretive case study conducted in Eastern Indonesia and framed within the concepts of information system (IS) artefacts, we find that tensions within and between information, technology, and social artefacts help to explain the sub-optimal LIS impacts. Inconsistent information, unsuitable technology, and conflicting social arrangements are examples of such tensions. Unless the tensions are properly resolved, LIS use cannot fulfil its potential for more appropriate management of land administration.
\end{abstract}

Keywords: eGovernment, Land information systems, Tension, Information system artefact, Indonesia, Developing country

\section{Introduction}

Information concerning land and land ownership is of critical importance for the development developing countries, facing severe challenges related to land management, including unclear responsibility distribution between the involved stakeholders [4], conflicting legal arrangements [5], and non-transparent systems [6]. Modern land information systems (LIS), consisting of a database containing spatially referenced data and procedures and techniques for the systematic collection, updating, processing and distribution of the data, are arguably a basic infrastructure for environmental management as well as economic and social development, particularly in developing countries [1]. Despite the advancements of more integrated LIS, conflicts over land [1], specifically uncontrolled land use and conversion [7], remain, with large areas of land remaining unregistered. While LIS play an important role within this field, research focusing on such issues has so far been rather incomplete [8].

We aim at contributing to this important field of interest by exploring LIS use in Indonesia. In 1997, Indonesia initiated the use of IS within their land management. However, the aforementioned problems remained unresolved [5, 7], and there have been a significant number of disputes reported over land. In 2007, for example, the 
National Land Agency (Badan Pertanahan Nasional [BPN]) recorded more than 7,000 cases of land conflicts covering almost 608,000 hectares of land [9]. By 2013, there were still more than 4,000 cases [10]. These conflicts occur for various reasons [11], such as illegal occupancy, border disputes, inheritance disputes, multiple sales, double certificates, false transaction letters, and overlapping borders. Until 2013, only around $45 \%$ of private ownership land parcels had been formally registered [10], which equals $5 \%$ of Indonesia's land area [12].

Given these considerations, it is clear that the effectiveness of LIS needs to be better understood. As will be further elaborated below, we found only sub-optimal use of LIS while conducting our fieldwork. Here, we aim to explore why by reflecting on the following research question: What can explain the sub-optimal impact of LIS use in Indonesia? To explore this, we conducted an interpretive case study in rural Eastern Indonesia (in the district of Nagekeo).

In order to fully understand the use and potential of introducing LIS, we need to understand technical, human [13], and contextual issues [14]. One way to do so is to introduce the concept of an ensemble artefact, which has been a core issue of concern within IS research [15]. We introduce the IS artefact concept, [15] which consists of three subsystems: the technology part, or the tools used to solve a problem, achieve a goal, or serve a purpose defined by humans; the information part, or the information instantiation occurring through a human act; and the social part, or the nature of the relationships or interactions between individuals (hence social) in attempts to solve problems, achieve goals, or serve one's purposes [16].

While Lee et al. [15] make an important theoretical contribution by clarifying the use of the term and emphasising IT artefacts' socio-technical elements, empirical work is still needed in order to further explore the IS artefact way of thinking. For instance, they argue that the 'whole IS artefact is greater than the sum of its subsystem' without really discussing how or why it is so. The framework talks about the three components as single entities, while in real-life examples there are several analysis units within each of these. Therefore, empirical work is still needed in order to better understand the connection between the three subsystems.

The IS artefact concept allows us to elaborate on the informational, technological, and social aspects of an ensemble artefact, but more emphasis is needed in order to understand potential conflicts between these subsystems, as well as how such conflicts could influence projects. We also introduce the concept of tensions to identify the challenges, internal or external, that must be managed so that the community can achieve the intended aims [17-19]. Tensions will lead to unstable conditions, oscillating between two different and competing states; this must be managed to ensure community survival over time [20]. Specific tensions should be carefully managed. As argued below, the identification of tension within the IS artefact subsystem allows us to further elaborate the understanding of why studied LIS achieved only a suboptimal impact.

This work's main contribution is twofold. First, we contribute by developing a more detailed understanding of LIS introduction by identifying tensions between IS artefact subsystems and their influence on LIS success (or otherwise). Second, by identifying these tensions, we contribute theoretically by providing a better explana- 
tion of tension's role between IS-artefact subsystems, a perspective so far being unexplored.

The rest of the paper is organised as follows: first, we introduce the theoretical premises for our works; then, before introducing our results, we briefly present the research context and approach. We conclude by discussing our findings and providing avenues for practice and future research

\section{Theoretical Premises}

The IS artefact concept is introduced here to provide a more detailed understanding of the technological, informational, and social aspects of the introduced LIS. The notion of 'artefact' has been highly debated within IS research [15] ever since the desperate call for more information technology (IT) artefact knowledge was raised by Orlikowski and Iacono [13]. The ensemble artefact view has its roots within the interpretation of IS being a socio-technical construction that ensures equal consideration of technical and human factors in the design process [21]. The socio-technical design's objective, 'the joint optimisation of the social and technical systems' [21], guides the idea of the ensemble view of an artefact [13] [22], as well as the IS artefact [15].

Scholars have recently criticised the artefact concept for being too broad and therefore no longer of value for IS research [23], while others argue for the need for more detailed exploration of IT artefacts [15, 24, 25]. The latter argument resonates with our view and is introduced here in order to explore LIS use within Indonesia, which allows for understanding the sub-optimal usage of such systems. Introducing the IS artefact perspective allows for focusing on how the system is dynamically shaped by the contextual dependencies of its context of use, adoption, and implementation [16].

The technology subsystem, the human-made tool created to solve a problem, achieve a goal, or serve a purpose, has several characteristics [15]. The technological subsystem does not include only digital or electronic components, but can also include non-digital parts of the system, such as face-to-face meetings, books, or paperbased library systems. Moreover, it might not be about information but still contain the technology, like the computer or the mobile phone. A technological subsystem does not need to have a physical representation [15]. The information subsystem is an information instantiation that is based on a direct or indirect human act [15]. Information can include numbers, letters, or symbols, or even relationships between such information tokens. Information is processed or adapted by an actor in order to achieve (or otherwise) the intended outcome. The social subsystem focuses on the relationships and interactions between individuals [15]. By focusing on interactions and relationships, this subsystem necessarily involves more than one individual, focusing instead on the social aspect. The social artefacts can include stable and established social relationships or more dynamic and fluid interactions.

According to Lee et al. [15], the IS artefact represents the technological, informational, and social subsystems and is more than the sum of its part, since part of the artefact relates to the relationship between its sub-systems. The features of both the technology and information subsystems are mainly seen as necessary conditions that 
render possible the social features through which users are linked to other content creators [26].The three subsystems are clearly assembled so that each component relates to the presence of the other. The three IS artefact subsystems, as well as how they are related, are summarised in Figure 1.

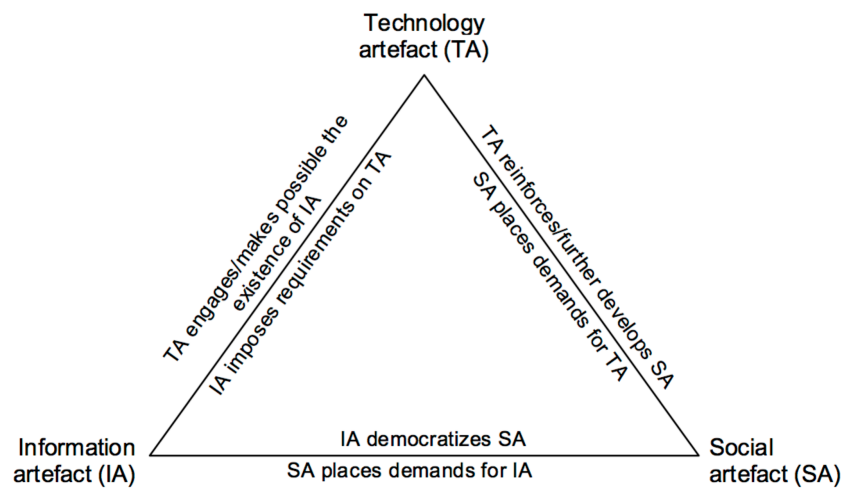

Figure 1. The 'triangle' relationships among IS artefacts (based on [15])

While the IS artefact perspective is useful in analysing various IT artefact characteristics and the relationships between them, less emphasis is placed on how these subsystems can conflict with each other, or how such conflicts potentially influence the success or otherwise when introducing ICT. We explore this perspective by looking at tensions between these subsystems. Tensions need to be managed; the question is how to combine 'sub-artefact' elements (internally and externally) to address these tensions.

Tensions can be defined as a state of contrast between opposite forces, each one leading an entity to a different - opposite - condition or state, or as a relationship between ideas and qualities with conflicting demands or implications. Out of these conditions, one could be the desirable while the other the undesirable. This concept is used by the literature in order to identify difficulties, internal or external, that could lead to an unstable oscillating condition between two different and competing states, which needs to be managed [27]. Focusing on tensions reveals the participants' conflicting goals, purposes, and motivations. They are not hidden; rather, as a form of sense-making, participants regularly discuss their problems as tensions [28].

\section{Research Context and Approach}

Indonesia, comprised of approximately 17,000 islands, covers an area of 1.9 million square kilometres $(\mathrm{km})$ supporting a population of more than 225 million people. During the 350 -year period before its independence in 1945, Indonesia was constantly under some form of colonial rule. Land law was dualistic, representing Western-style systems - to meet the colonial governments' interests - and traditional unwritten laws based on customary rights to land, which exist in Indonesia's diverse cultural groups. This dualism in land law was expected to end in 1960 with the enactment of the Basic 
Agrarian Law (Undang-Undang Pokok Agraria). This national law recognises traditional concepts and institutions, while at the same time provides for the registration of individual land rights. Within this framework, Indonesia operates a complex land management system [29].

The legal issues are complex, as land administration is managed under two national government agencies, BPN and the Ministry of Forestry (MoF). These government agencies refer to different laws in determining land borders under their jurisdiction [30]. To some extent, this policy leads to conflicts and power struggles between land management officials and Indonesian administration [5, 30].

Our study site is the district of Nagekeo located in the province of East Nusa Tenggara (see Figure 1). Approximately 110,000 people inhabit this area, which covers 1,417 square $\mathrm{km}$. This newly established district was part of the district of Ngada until 2007. A large proportion of this district's land is community land (tanah ulayat) without certificates. That often triggers land conflicts, either between tribal groups or between tribal groups and the local government [31, 32]. Nagekeo was selected in order to represent an area where conflicts concerning community land ownership are prevalent.

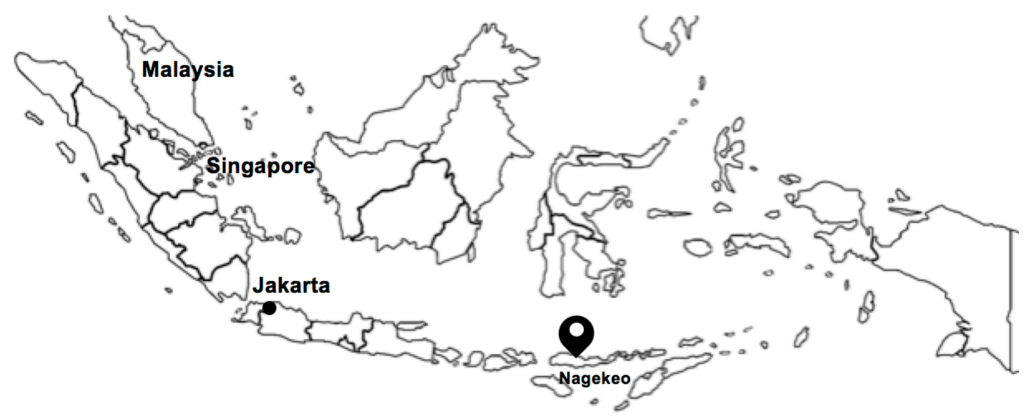

Figure 2. Map of Nagekeo: The study site

Nagekeo's local BPN office was officially founded in 2010. One year later the office introduced Larasita, a mobile land office (a modified van) that services remote areas and is equipped with laptops connected through a virtual private network to the national BPN office's main databases. They use a LIS called Geo-KKP, which is a web-based system that connects textual and spatial land data. Technically, a LIS is already in place, to some extent, in order to support certification and other related services.

One of the flagship programmes established by BPN and the national government intended to speed up asset legalisation (i.e. certification of lands). To this end, BPN launched the Prona scheme, which offered free block registration to certain disadvantaged communities. In Nagekeo, the local BPN office expects to issue 1,200-1,400 land certificates annually. Of these, 800 certificates were through the Prona scheme (where 75 certificates were allocated to fishermen). This number is considered low, since only $5 \%$ of Nagekeo land has been certified to date. 


\subsection{Research Approach}

In this interpretative case study, data were collected primarily through interviews with actors from different backgrounds: farmers, fishermen, BPN service users, the heads of tribal groups, members of cooperatives, financial institutions (i.e. bank), and government officers from district, sub-district, and village levels. These informants represent the various stakeholders involved in land-related issues, representing both the people and the government. Stakeholders from the people's side include the head of tribal groups, (migrant/local) farmers, (migrant/local) fishermen, and local businessmen. On the government's side, there is BPN, a local planning agency, and various departments responsible for forestry, settlement, city planning, and the development of the fishery sector and small and medium-sized enterprises.

In total, we conducted 25 interviews with 31 informants, whereof 20 interviews were carried out in Nagekeo including 24 informants. In order to provide a broader national perspective, the rest of the interviews were done with Jakarta BPN officers at the Geospatial Information Agency (Badan Informasi Geospasial [BIG]) in Bogor and Jakarta's WWF Indonesia. All of the interviews were either recorded or extensively noted.

In analysing the data, we used the concepts depicting the artefact relationships (i.e. information, technology, and social) composing the IS artefact as the coding template. We identified all of the tensions that happened in all of the relationships and mapped them into specific relationships. When the tensions involve at least two different instantiations at the same artefact, we termed them as 'tensions within artefacts'. Otherwise, when more than one composing artefact is involved in the tensions, we named them 'tension between artefacts'.

\section{$4 \quad$ Findings}

Before presenting the main findings on the tensions within and between IS artefacts, it is necessary to identify examples of each composing artefact (i.e. information, technology, and social) in play within the LIS uptake context. Information artefact (IA) examples include land-related laws, information on procedures for land certification application, costs that may be incurred, the consequences of having certified land (e.g. paying annual land tax, securing land ownership), and the land certificate itself. The technology artefacts identified included all technologies that constitute the LIS, such as Internet, virtual private network (VPN), a modified van for Larasita, laptops, other network infrastructure, land measurement tools, and the information system applications (e.g. Geo-KKP). The social artefacts comprised of all possible relationships and interactions among the involved actors (e.g. citizens, BPN, local government agencies, head of tribal groups).

\subsection{Tensions within artefacts}

First, we present the findings indicating the tensions found within each composing artefact. 
Within information artefact. This artefact manifest in various forms. Unclear or conflicting information on many aspects can create tension. For example, one village official says, 'Prona is prioritised for those with low economic status, and it's free of charge'. But in the field, we found that some informants are expected to pay certain amounts of money. One BPN official says in defence, 'Well, the village might charge something. But that's their village's regulations. The thing is, BPN doesn't charge anything'. One informant further asserts, 'The payment [for BPN employees in the field during the measurement process] is unclear which may result in corruption and manipulation. It is because of unclear payment for transport, food, and accommodation. This type of payment for land certification tends to be expensive. This discourages people to certify their land'. Another tension within information artefact is illustrated by one national BPN office director, who asserts, 'There are 13 laws related to land which are not harmonised, either horizontally among the laws or vertically with their references, namely the constitution'.

Within technology artefact. The modified Larasita van was originally designed to provide mobile land certification services directly to the citizens, especially those residing in remote areas. But, as one BPN official tells us, 'It's because we moved the office and there were problems with Internet network. We have no network at all... I think Larasita's van hasn't had it yet. The van is just an operational vehicle when we need to go to the field. ... We haven 't been able to run Larasita properly'.

Within social artefact. Land certification is not available for everyone, since many fishermen do not own their lands - a landlord (the tribal group) does. Potential land ownership conflicts can also hinder land certification. We found that many of the land certification applications sent to BPN were going nowhere, even after many years, because indigenous people are claiming back the land. In such cases, BPN never issues certificates over those lands. One informant illustrates, 'Well here, the problems related to lands are usually among the society, related to the tribal groups, within the tribal groups, among individuals, and the most frequently is related to the government'. Another informant adds, 'The government wants to do something, but the society feels that the lands are their living sources so they refuse it. Conflicts happen then'. Further, another informant asserts, 'Sometimes the government is not neutral, they are not strict. And related to the border problems, there hasn't been one solved so far'.

Table 1 summarises examples of tensions between instantiations within a composing artefact.

Table 1. Tensions within artefact

\begin{tabular}{|c|l|l|}
\hline No. & Artefact & Example of identified tension \\
\hline 1 & IA x IA & Inconsistent information about the cost for certifying a land parcel. \\
\hline 2 & TA x TA & $\begin{array}{l}\text { The national BPN office's designed technology does not fit the availa- } \\
\text { ble local infrastructure. }\end{array}$ \\
\hline 3 & SA x SA & Disputes between tribal groups over land claims. \\
\hline
\end{tabular}




\subsection{Tensions between artefacts}

Next, we present the identified tensions between instantiations from two different artefacts. These tensions happen when the involved artefact's relationship goes in an unexpected direction. Each of the identified tensions is presented below.

Between technology and information artefact. A technology artefact can engage, or make possible, the existence of an information artefact. As the main LIS application, Geo-KKP provides and connects textual and spatial land data. However, it only records the already certified private lands; it does not provide information about uncertified land borders. These lead to land disputes. One local BPN office official coments: 'For measurement, the common problem is any claims related to the land borders among the society. ... For the measurement workers, they should clear the problems right away. We look for win-win solution. We set the border both sides agree to it'.

Between information and technology artefacts. An information artefact can impose requirements on a technology artefact. Even though the national government enacted a law in 2011 concerning geospatial information to provide legal support for the 'One Map Policy' initiative, Geo-KKP does not have an integrated map, which is managed by the Ministry of Forestry (MoF). Both BPN and MoF refer to different laws in determining land borders under their jurisdiction, which is substantiated by tales from the field. An official from the local government states, 'There should be a proposal from village people for land certification. With the proposal, BPN will investigate in the field for issuing the land certificate. However, BPN always coordinate with the Department of Forestry, especially to get recommendation that the lands for certification are not within the government forests'.

Between technology and social artefacts. The use of technology can either further improve or hurt social artefacts. As one informant says, 'By having technology, there are many references that can be searched, so there will be plenty of sources that can be adopted. Moreover, there will be new insights. Therefore, if they know the technology better, they may be able to clear the facts'. However, he later adds, 'It may create the problem ... if the people actually do not play an important role, but they know technology very well. Finally, they can manipulate the truth. And actually, the problems here are because the acknowledgement among the tribes does not get stronger'. In a different fragment, another informant tells us, 'The previous BPN officials were not good and worked very slow. If people want to speed up their land certification process, they just give some money as greasing oil'.

Between social and technology artefacts. The social artefact can place demand for the technology artefact. Moreover, lack of education restricts the use of technology. When asked about the conflict's nature, one informant asserts, 'So far, it is the personal conflict, because all people obey the head of tribal group, when it is customary conflict. The difficult part is the informal claim, such claiming certain lands, which belong to other people. This is basically related to the technology and educational level of the community. For example, people who are well educated, they sometimes even become the one who start the problem. The real owner can lose the case because 
they have lower education'. In this case, social relation problems cannot always be resolved by the help of technology.

Between social and information artefacts. The social artefact can also place demand for an information artefact. However, this is not always the case in practice. When discussing land certification challenges, one informant clearly explains, 'There are two main challenges. The first one relates to administration where people could not provide with administrative proof of owning the lands. The second one is that different claims over the same land that is proposed for land certification. This disputed claims over lands use to occur in the customary lands'. Here, the tribal group's social arrangement does not allow the group members to certify their lands.

Between information and social artefacts. An information artefact can democratise a social artefact, such as by providing accessible and symmetric information. In our case, however, this relation is disrupted. One migrant farmer states, 'The certificate for the land of this house has been issued. ... But the land of rice field [certificate] has not been issued yet. ... Although measurement had been conducted'. When asked for the reason behind this, he says, 'I don't know, as it is the government's responsibility. We do not know because we are only stupid people'. However, he should pay land taxes for both parcels of land. He further tells us, 'Fifty thousand for the yard [the house]. ... For the rice fields, it is 100 thousand per year'. In fact, in 2014, the national BPN office launched a SMS service that enable the land certification applicants to obtain a variety of information, such as measurement cost, land rights transfer cost, and complaints. The informants that we interviewed did not use this service. The un-informed people have no choice other than doing what government officials should do. Table 2 summarises the composing artefact tensions.

Table 2. Tensions between artefacts

\begin{tabular}{|c|l|l|}
\hline No. & Relationship & Example of identified tension \\
\hline 1 & TA x IA & $\begin{array}{l}\text { The existing LIS does not provide information on borders of uncer- } \\
\text { tified lands. }\end{array}$ \\
\hline 2 & IA x TA & $\begin{array}{l}\text { The requirement to have information on the border between private } \\
\text { lands and government forestlands is not readily available in the } \\
\text { existing LIS. }\end{array}$ \\
\hline 3 & TA x SA & The existent LIS does not always speed up the certification process. \\
\hline 4 & SA x TA & $\begin{array}{l}\text { The problems in social relations that create land ownership disputes } \\
\text { cannot be resolved by the technology in place. }\end{array}$ \\
\hline 5 & SA x IA & $\begin{array}{l}\text { The tribal group's social arrangement does not allow the group } \\
\text { members to certificate their lands. }\end{array}$ \\
\hline 6 & IA x SA & $\begin{array}{l}\text { The un-informed people have no choice other than doing what } \\
\text { government officials should do. }\end{array}$ \\
\hline
\end{tabular}

\section{Discussion}

The findings presented above support our projection that tensions emerge when LIS' social and technical aspects interact. The concept of the IS artefact, with its composing artefacts that we used as an analytical lens, helps us in unveiling these tensions. 
We also found that each composing artefact is not a single uniform entity, but rather another smaller ensemble consisting of a variety of artefact instantiations from the same class. These instantiations do not always go hand in hand or interact without any problem. We found, for example, that information artefacts can manifest in various forms and versions. If these versions are not congruent, tensions can occur. Another example is within the social artefact, such as when different tribal groups fail to find agreement on certain land borders.

We also found tensions between composing artefacts. These happen when an artefact cannot play its role, or when the relationships do not develop as expected. For example, LIS as a technology artefact cannot provide information about uncertified lands (such as between forestlands and community lands), as the information is not readily available. This is beyond LIS capabilities because the social artefacts in question (such as between tribal groups and the department of forestry) have not yet agreed on the disputed land borders. This tension will hinder LIS in fulfilling its promises to speed up land certification. Figure 2 illustrates the identified tensions both within and between the three composing artefacts.

The findings indicate that if tensions within and between artefacts are not properly resolved, they will limit the ability of an IS artefact (in this case, LIS) to be optimally harvested. In our study site, land-related problems are very prevalent or even escalating, which may trigger long lasting social conflicts $[31,32]$. Theoretically, the IS artefact concept equips us with vocabularies for identifying the building blocks of LIS and their relationships, but this does not provide further possibilities for explaining possible problems when the relationships do go in the expected directions. Using just the IS artefact concept, we can only draw a foggy picture. By bringing in the concept of tensions, we sharpen the analytical lens and make the picture clearer.

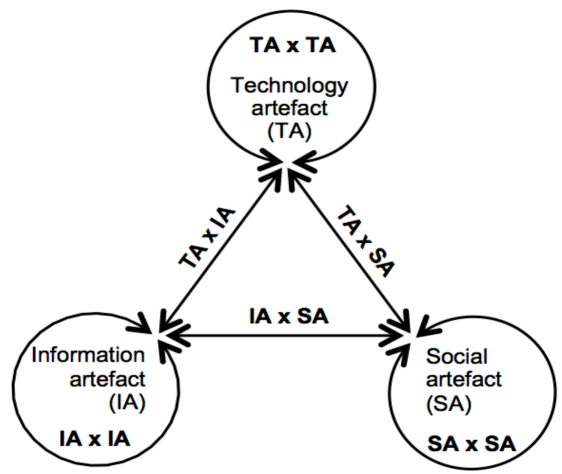

Figure 3. Tensions within and between the composing IS artefacts

From a conceptual viewpoint, our study contributes to extending the IS artefact concept [15] by introducing the concept of tensions in order to explain unexpected results that occur when the composing artefacts interact. We can then explore how the relationship between instantiations within and between composing artefacts are dialectical and therefore not always moving in positive directions. By this improved analytical lens, we contribute practically to the field development of eGovernment within ICT4D research by providing a clear explanation for the emerging problems when a nationally designed initiative is implemented in various local contexts. 


\section{Conclusion}

We have here discussed a case study that explore the LIS' sub-optimal impact in Indonesia. In so doing, we developed a sharper analytical lens by introducing the concept of tension in order to extend the IS artefact concept [15]. Our study found that tensions within and between the technology, information, and social artefacts (the composing artefacts) restrict the optimal impact LIS may have.

Our study offers two main contributions. First, it offers a more detailed understanding of LIS introduction within Indonesia by identifying tensions between the composing IS artefacts, as well as their influence on LIS success (or otherwise). Second, it proposes to incorporate the concept of tensions into the IS artefact concept to provide a better explanation of tension's role between the composing artefacts.

More work is needed to further elaborate on the findings introduced here, which is based on one single case study and therefore has only limited possibilities for provide all possible explanations. Future studies should go more into detail by unpacking each composing artefact and exploring other important composing artefacts. For example, the social artefact can be broken down into various artefacts, including political and legal artefacts, as already called for [33]. Scrutinising a phenomenon using more granulated artefacts could reveal a richer picture and more detailed practical insights, providing avenues for further research.

\section{References}

1. Arko-Adjei, A.: A conceptual approach for enhancing customary land management: Case from Ghana. 5th FIG Regional Conference: Promoting Land Administration and Good Governance, Accra, Ghana (2006)

2. Huber, M., Mithöfer, K., Schär, P., Harvey, F., Mukasa, O.: Universal land registry to support independent economic development in Tanzania. The Tenth GSDI Conference, St. Augustine, Trinidad (2008)

3. Silva, L.: Institutionalization does not occur by decree: Institutional obstacles in implementing a land administration system in a developing country. Information Technology for Development 13, 27-48 (2007)

4. Bennett, R., Rajabifard, A., Williamson, I., Wallace, J.: On the need for national land administration infrastructures. Land Use Policy 29, 208-219 (2012)

5. Bakker, L., Moniaga, S.: The space between: Land claims and the law in Indonesia. Asian Journal of Social Science 38, 187-203 (2010)

6. Chawla, R., Bhatnagar, S.: Online delivery of land titles to rural farmers in Karnataka, India. Scaling Up Poverty Reduction: A Global Learning Process and Conference. World Bank, Shanghai (2004)

7. Firman, T.: Major issues in Indonesia's urban land development. Land Use Policy 21, 347355 (2004)

8. Furuholt, B., Wahid, F., Sæbø, Ø.: Land Information Systems for Development (LIS4D): A Neglected Area within ICT4D Research? In: Proceedings of the 48th Hawaii International Conference on System Sciences (HICSS 2015), pp. 2158-2167. IEEE, (2015)

9. Winoto, J.: Taking land policy and administration in Indonesia to the next stage and National Land Agency's strategic plan. Workshop in International Federation of Surveyors' Forum, Washington DC (2009)

10. Badan Pertanahan Nasional, http://www.bpn.go.id/Publikasi/Data-Pertanahan/KasusPertanahan/Nasional 
11. Badan Pertanahan Nasional, http://www.bpn.go.id/Program-Prioritas/Penanganan-KasusPertanahan

12. Yusuf, H.: Land administration system in Indonesia. Pre-17th AVA Congress, Siem Reap, Cambodia (2011)

13. Orlikowski, W.J., Iacono, C.S.: Research commentary: Desperately seeking the "IT" in IT research-A call to theorizing the IT artifact. Information Systems Research 12, 121-134 (2001)

14. Davison, R.M., Martinsons, M.G.: Context is king\&excl; Considering particularism in research design and reporting. Journal of Information Technology 31, 241-249 (2016)

15. Lee, A.S., Thomas, M., Baskerville, R.L.: Going back to basics in design science: from the information technology artifact to the information systems artifact. Information Systems Journal 25, 5-21 (2015)

16. Spagnoletti, P., Resca, A., Sæbø, Ø.: Design for Social Media Engagement: Insights from elderly care assistance. The Journal of Strategic Information Systems 24, 128-145 (2015)

17. Ågerfalk, P.J., Fitzgerald, B.: Outsourcing to an unknown workforce: Exploring opensurcing as a global sourcing strategy. MIS Quarterly 32, 385-409 (2008)

18. Hutter, K., Hautz, J., Füller, J., Mueller, J., Matzler, K.: Communitition: the Tension between competition and collaboration in community-based design contests. Creativity and Innovation Management 20, 3-21 (2011)

19. Kozinets, R.V., De Valck, K., Wojnicki, A.C., Wilner, S.J.S.: Networked narratives: Understanding word-of-mouth marketing in online communities. Journal of marketing 74,71 $89(2010)$

20. Faraj, S., Jarvenpaa, S.L., Majchrzak, A.: Knowledge collaboration in online communities. Organization science 22, 1224-1239 (2011)

21. Mumford, E.: The story of socio-technical design: Reflections on its successes, failures and potential. Information Systems Journal 16, 317-342 (2006)

22. Sein, M., Henfridsson, O., Purao, S., Rossi, M., Lindgren, R.: Action Design Research. MIS Quarterly 35, 37-56 (2011)

23. Alter, S.: The concept of 'IT artifact' has outlived its usefulness and should be retired now. Information Systems Journal 25, 47-60 (2015)

24. Goldkuhl, G.: The IT artefact: An ensemble of the social and the technical?-A rejoinder. Systems, Signs \& Actions 7, 90-99 (2013)

25. Silver, M.S., Markus, M.L.: Conceptualizing the SocioTechnical (ST) artifact. Systems, Signs \& Actions 7, 82-89 (2013)

26. Kaplan, A.M., Haenlein, M.: Users of the world, unite! The challenges and opportunities of Social Media. Business horizons 53, 59-68 (2010)

27. Salem, P.: The seven communication reasons organizations do not change. Corporate Communications: An International Journal 13, 333-348 (2008)

28. Ribes, D., Finholt, T.A.: The long now of technology infrastructure: articulating tensions in development. Journal of the Association for Information Systems 10, 375 (2009)

29. Heryani, E., Grant, C.: Land administration in Indonesia. 3rd FIG Regional Conference, Jakarta (2004)

30. Sekretariat Kabinet, http://www.setkab.go.id/berita-8452-redam-konflik-penguasaan-lahanbadan-informasi-geospasial-susun-satu-peta-dasar.html

31. Suara Pembaruan: Sengketa tanah ulayat di Nagekeo, NTT: Bupati diduga pakai polisi sebagai beking. Suara Pembaruan, (2014)

32. Rahalaka, K.: Pendekatan budaya, solusi penyelesaian masalah tanah di Nagekeo. Floresbangkit.com (2014)

33. Winner, L.: Do artifacts have politics? Daedalus 109, 121-136 (1980) 